PRECARIOUS HOPE 
This page intentionally left blank 


\section{PRECARIOUS HOPE}

Migration and the Limits of

Belonging in Turkey

AYŞE PARLA 
Stanford University Press

Stanford, California

(C) 2019 by the Board of Trustees of the Leland Stanford Junior University.

All rights reserved.

No part of this book may be reproduced or transmitted in any form or by any means, electronic or mechanical, including photocopying and recording, or in any information storage or retrieval system without the prior written permission of Stanford University Press.

Printed in the United States of America on acid-free, archival-quality paper Library of Congress Cataloging-in-Publication Data

Names: Parla, Ayşe, author.

Title: Precarious hope : migration and the limits of belonging in Turkey / Ayşe Parla.

Description: Stanford, California : Stanford University Press, 2019. | Includes bibliographical references and index.

Identifiers: LCCN 2019009009 (print) | LCCN 2019009649 (ebook) | ISBN 9781503609440 (e-book) | ISBN 9781503608108 (cloth : alk. paper) | ISBN 9781503609433 (pbk. : alk. paper)

Subjects: LCSH: Immigrants-Turkey-Social conditions. | Turks-Bulgaria-Social conditions. | Citizenship-Turkey. | National characteristics, Turkish. | Emigration and immigration law-Turkey. | Turkey-Emigration and immigration. | Bulgaria-Emigration and immigration.

Classification: LCC JV8745 (ebook) | LCC JV8745 .P37 2019 (print) | DDC 305.9/0691209561-dc23

LC record available at https://lccn.loc.gov/2019009009

Cover design: Kevin Barrett Kane

Cover photograph: Behiç Günalan

Typeset by Motto Publishing Services in 10/14 Minion Pro 
For my parents, Jale and Taha 
This page intentionally left blank 